\section{Курочкин}

\section{Сергей Анатольевич,}

доцент кафедры теории

государства и права

Уральского государственного

юридического университета, кандидат юридических наук

tgp®usla.ru
DOI: 10.18572/1812-383X-2020-12-38-42

\section{Эффективные проверочные производства в гражданском и арбитражном процессе}

Проверочные инстанции имеют ключевое значение в обеспечении эффективности судебной защиты, выступают важным условием действенной реализации права на исправление судебной ошибки, минимизируют издержки судебного разбирательства. Какова роль апелляции и кассации в обеспечении эффективности гражданского судопроизводства на современном этапе? Требуют ли рационализации проверочные процедуры еще одного, четвертого уровня? Ответы на эти вопросы предложены в настоящей статье.

Ключевые слова: гражданское судопроизводство, судебная защита, эффективность, апелляция, кассация, издержки.

\title{
Efficient Verification Proceedings in a Civil and Arbitration Procedure
}

\section{Kurochkin Sergey A.}

Associate Professor of the Department of Theory of State and Law of the Ural State Law University

$\mathrm{PhD}$ (Law)

Judicial instances are the factors of key importance in ensuring the effectiveness of court protection, an important condition for the effective implementation of the right to correct a judicial error, and minimize the costs of civil litigation. What is the role of appeal and cassation in ensuring the efficiency of Russian civil procedure at the present stage? Do verification procedures need to be rationalized at a fourth level? The answers to these questions are offered.

Keywords: civil litigation, judicial protection, efficiency, appeal, cassation, costs. 